DOI: 10.46340/eujem.2020.6.5.11

\author{
Hanna Koptieva, PhD in Economics \\ ORCID ID : https://orcid.org/0000-0002-3082-2094 \\ National Technical University "Kharkiv Polytechnic Institute», \\ Ukraine
}

\title{
METHODOLOGICAL BASES \\ FOR ASSESSING THE ECONOMIC SECURITY \\ OF TRADE ENTERPRISES BASED ON THE MATURITY OF THEIR BUSINESS PROCESSES
}

The results of the conducted research substantiate the scientific and methodical approach for assessing economic security of the trade enterprise on the basis of maturity of its business processes. The developed approach is based on the method of fuzzy logic, which makes it possible to establish the level of economic security of the trade enterprise on the basis of the maturity of its business processes with incomplete data available. The developed approach contains two types of maturity assessment - individual business processes and process management at the enterprise as a whole - and provides for step-by-step calculations for assessing the state of business processes of a trade enterprise, taking into account the interests of stakeholders, identifying the completeness of business process, assessing the business processes maturity, and establishing the type of economic security at the enterprise. To implement the developed scientific and methodological approach, a system of indicators is substantiated which is formed taking into account the criteria of performance, efficiency, and satisfaction of consumers with the results of the business process.

Keywords: business process, economic security of the enterprise, method of fuzzy logic, system of indicators, criteria of performance, efficiency, and satisfaction, international trade networks.

Introduction. Economic security of the enterprise is a complex concept, which the academic literature presents basically as a set of certain elements, formed with reference to the functional approach to enterprise management in general and security in particular. This perspective gives significant advantage when studying economic security, providing the ability to determine the quality of work of the units and provide rationalization for measures to improve the activities of business in certain areas - sales, marketing, finance, and personnel management for a trade enterprise. Despite these advantages of a functional approach, however, it does not ensure a uniform understanding of the condition of economic security of the enterprise. Determining the level of economic security using not a differentiation, as it happens in the case of a functional approach, but a combination of functions by departments of the enterprise, may be achieved by process management and security assessment based on the business processes maturity. Implementation of measures to improve the economic security of the enterprise based on the business processes maturity makes it possible to optimize the operating and investment activities of the business and ensures its protection from the risks of inconsistent implementation of measures by areas of activity. The dependence of methods and technologies of economic security management on the state of business processes at the enterprise makes the assessment of their maturity level relevant.

The analysis of bibliography indicates a wide range of issues of process maturity, which are the subject matters of the academic publications. This problem is considered in the academic literature in the context of analysis of models of maturity, their formation, areas and results of use at the enterprise, adaptation of the developments available to the practice of enterprises, and rationale for original methods, based on global experience in process management assessment. Despite there are numerous basic models for assessing the 
business process maturity and modification of the same ${ }^{1}$, the use of these models to assess the economic security of business processes of a trade enterprise needs to be adapted to the object of research, trade enterprises, and the subject of research, economic security of their business processes.

Purpose. The aim of research is to develop a scientific and methodological approach to assessing the level of economic security of business processes of a trade enterprise based on the business process maturity. The objective of the research is to generalize theoretical and methodological provisions for assessing economic security, business processes maturity, and on this basis to develop a sequence for assessing the economic security of an enterprise based on the business processes maturity and practical evaluation of it according to a selection.

Brief Literature Review. The developed scientific and methodological approach is based on theoretical provisions on the essence of economic security, components of business processes and features of their implementation in trade, as well as the substantive characteristics of maturity and conditions for establishing their levels obtained by critical analysis and generalization of their definitions and components provided in the works ${ }^{2}$. The methodological basis of the developed scientific and methodological approach was formulated by the studies of methodological approaches and tools for assessing economic security in the works of Vasyltsiv T.H., Voloshyn V.I., Boikevych O.R., Karkavchuk V.V. (2012)3 , business processes maturity in the work of Bruin T., Kulkarni U., Rosemann M., Freeze D.R. (2005) ${ }^{4}$, Garousi V., Felderer M., Hacaloglu T. (2017)

${ }^{1}$ Tarhan, A., Turetken, O., Reijers, A. H. (2016). Business process maturity models: A systematic literature review. Information and Software Technology, 75, 122-134. DOI:10.1016/j.infsof.2016.01.010; Roeglinger, M., Poeppelbuss, J., Becker, J. (2012). Maturity Models in Business Process Management. Business Process Management Journal, 18 (2), 328-346. DOI: 10.1108/14637151211225225; Bruin, T., Kulkarni, U., Rosemann, M., Freeze, D.R. (2005).

Understanding the Main Phases of Developing a Maturity Assessment Model. 16th Australasian Conference on Information Systems, Sydney <https://pdfs.semanticscholar.org/c00f/91faf37a75823a5baca7415a5123ac4010f8.pdf> (2020, July, 10); Rohloff, M. (2011). Advances in business process management implementation based on a maturity assessment and best practice exchange. Information Systems and e-Business Management, 9, 383-403.

DOI:10.1007/s10257-010-0137-1; Sliż, P. (2018). Concept of the Organization Process Maturity Assessment. Journal of Economics and Management, 33 (3), 80-95. DOI: 10.22367/jem.2018.33.05; Paulk, M. C., Chrissis, M. B., Weber, C. (1993). Capability Maturity Model for Software (Version 1.1). Technical report.

$<$ https://resources.sei.cmu.edu/library/asset-view.cfm?assetid=11955> (2020, July, 10); Carolis, A. De, Macchi, M., Negri, E., Terzi, S.A. (2017). Maturity Model for Assessing the Digital Readiness of Manufacturing Companies. IFIP WG 5.7 International Conference, APMS, Hamburg, Germany, Proceedings, I, 13-20. <https://link.springer.com/chapter/10.1007/978-3-319-66923-6_2> (2020, July, 10); Garousi, V., Felderer, M., Hacaloglu, T. (2017). Software test maturity assessment and test process improvement: A multivocal literature revier. Information and Software Technology. DOI:10.1016/; Vivares, A. J., Sarache, W., Hurtado, J. (2018). A maturity assessment model for manufacturing systems. Journal of Manufacturing Technology Management, 29, 5, $746-767$. DOI:10.1108/JMTM-07-2017-0142; Zare, S. M., Tahmasebi, R., Yazdani, H. (2018). Maturity assessment of HRM processes based on HR process survey tool: a case study. Business Process Management Journal, 24, 3, 610-634. DOI:10.1108/BPMJ-01-2017-0008; Vereecke, A., Vanderheyden, K., Baecke, Ph., Van Steendam, T. (2018). Mind the gap - Assessing maturity of demand planning, a cornerstone of S\&OP. International Journal of Operations \& Production Management, 38, 8, 1618-1639. DOI:10.1108/IJOPM-11-2016-0698.

${ }^{2}$ Васильців, Т. Г., Волошин, В. І., Бойкевич, О. Р., Каркавчук, В. В. (2012). Фінансово-економічна безпека підприсмтв України: стратегія та механізми забезпечення: монографія. Львів: Ліга-Прес, 388.

<http://ird.gov.ua/irdp/p20120802.pdf> (2020, July, 10); Пилипенко, А. А., Пилипенко, С. М. (2019). Оцінювання зрілості логістичної діяльності в управлінні економічною безпекою розвитку об'єднань торговельних підприємств. Науково-виробничий журнал Бізнес-навігатор, 6.1-1(56), 219-222; ISO 9000:2015 (2015). Quality management systems - Fundamentals and vocabulary. <https://www.iso.org/ru/standard/45481.html> (2020, July, 10); Король, С. Я. (2016). Соціальна відповідальність бізнесу: теорія та методологія обліку: монографія. Київ: KНTЕУ, 416; Bruin, T., Kulkarni, U., Rosemann, M., Freeze, D.R. (2005). Understanding the Main Phases of Developing a Maturity Assessment Model. 16th Australasian Conference on Information Systems, Sydney $<$ https://pdfs.semanticscholar.org/c00f/91faf37a75823a5baca7415a5123ac4010f8.pdf> (2020, July, 10).

${ }^{3}$ Васильців, Т. Г., Волошин, В. І., Бойкевич, О. Р., Каркавчук, В. В. (2012). Фінансово-економічна безпека підприємств Украӥни: стратегія та механізми забезпечення: монографія. Львів: Ліга-Прес, 388. <http://ird.gov.ua/irdp/p20120802.pdf> (2020, July, 10);

${ }^{4}$ Bruin, T., Kulkarni, U., Rosemann, M., Freeze, D.R. (2005). Understanding the Main Phases of Developing a Maturity Assessment Model. 16th Australasian Conference on Information Systems, Sydney.

<https://pdfs.semanticscholar.org/c00f/91faf37a75823a5baca7415a5123ac4010f8.pdf> (2020, July, 10).

${ }^{5}$ Garousi, V., Felderer, M., Hacaloglu, T. (2017). Software test maturity assessment and test process improvement: A multivocal literature revier. Information and Software Technology. DOI:10.1016/. 
Paulk M.C., Chrissis M. B., Weber C. (1993) ${ }^{1}$ and the state of systems in the works of Pylypenko A.A., Pylypenko S.M. (2019) ${ }^{2}$, Klebanova T.S. Chahovets L.O., Panasenko O.V. (2011) $)^{3}$, Nedosekin A.O. (2003) 4 Based on the analysis of the developments available in these areas, the methodological approach to assessing the economic security of a trade enterprise based on the maturity of its business processes is based on the fuzzy set method, which makes it possible to determine the level of economic security of the business when having incomplete information which is typical of comparative assessment, and competitive analysis.

Results. The developed scientific and methodological approach to assessing the economic security of a trade enterprise based on the maturity of its business processes using fuzzy logic is implemented in stages, which provide for assessing the security of business processes taking into account the interests of stakeholders, completeness of business processes implementation, and economic security of a trade enterprise. Each of the stages is implemented by means certain methods. The stage of assessing the security of business processes taking into account the interests of stakeholders is carried out using observation, calculation of averages, coefficient method, method of dynamic analysis, scoring, fuzzy logic, additive reduction, taking into account the strength of components. The stage of identifying the completeness of the implementation of business processes is based on the observation and use of linguistic variables. The stage of economic security assessment provides for the integration of the results of assessing the security of business processes (stage 1) and the completeness of business processes implementation (stage 2) and substantiation of the conclusion on this basis on the level of economic security of a trade enterprise, based on fuzzy logic.

The order of calculations by these stages is as follows.

Stage 1. Assess the security of business processes taking into account the interests of stakeholders (determine the purpose of the research; determine indicators of the condition of business processes of a trade enterprise taking into account the interests of stakeholders; determine the state of business processes of a trade enterprise taking into account the interests of stakeholders; to conclude on the state of business processes, taking into account the interests of stakeholders).

Stage 2. Identify the completeness of business processes implementation. The following linguistic variables will be used to determine the completeness of implementation of business processes: "very poor", "low", "medium", "high", "very high".

Stage 3. Assess the economic security of the trade enterprise (determine the purpose of the study; determine the maturity of business processes of the trade enterprise).

When calculating, take into account the following conditions:

a) The linguistic variable "Level of Business Process Maturity" (Q) has the following meanings:

Q1 - the $0^{\text {th }}$ level (highest level of danger);

Q2 - the $1^{\text {st }}$ level (initial - low level of security);

Q3 - the $2^{\text {nd }}$ level (standard - minimum required security level);

Q4 - the $3^{\text {rd }}$ level (rational and formalized - sufficient level of security);

Q5 - the $4^{\text {th }}$ level (controlled and managed - high level of security);

Q6 - the $5^{\text {th }}$ level (ultimate with constant development - the highest (absolute) level of security).

b) The linguistic variable "Attribute State" (A) has the following term-sets of values:

A1 - unacceptable state;

A2 - very poor state;

A3 - poor state;

A4 - not bad state;

A5 - good state;

A6 - very good state.

\footnotetext{
${ }^{1}$ Paulk, M. C., Chrissis, M. B., Weber, C. (1993). Capability Maturity Model for Software (Version 1.1).

Technical report. <https://resources.sei.cmu.edu/library/asset-view.cfm?assetid=11955> (2020, July, 10).

${ }^{2}$ Пилипенко, А. А., Пилипенко, С. М. (2019). Оцінювання зрілості логістичної діяльності в управлінні економічною безпекою розвитку об'єднань торговельних підприємств. Науково-виробничий журнал Бізнеснавігатор, 6.1-1(56), 219-222.

${ }^{3}$ Клебанова, Т. С., Чаговець, Л. О., Панасенко, О. В. (2011). Нечітка логіка та нейронні мережі в управлінні підприємством : монографія. Харків: ІНЖЕК.

${ }^{4}$ Недосекин, А. О. (2003). Методологические основы моделирования финансовой деятельности с использованием нечетко-множественных описаний: диссертация на соискание ученой степени доктора экономических наук. Санкт-Петербург: Санкт-Петербургский государственный университет экономики и финансов (ФИНЭК), 280. <http://www.mirkin.ru/_docs/doctor005.pdf> (2020, July, 10).
} 

used $^{1}$ :

To determine the maturity of the business process of a trade enterprise the following formula can be

$$
\begin{gathered}
Q_{m}=\sum_{j=1}^{6} q_{j} \sum_{i=1}^{n} r_{i} \varphi_{i j}, \\
r_{i}=\frac{1}{N},
\end{gathered}
$$

where $Q m$ - maturity indicator of m-business process, ratio;

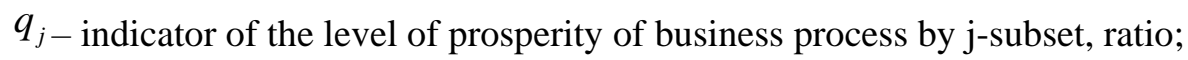

$r_{i-\text { indicator of importance of i-attribute; }}$

$N$ - number of attributes;

$\varphi_{i j}$ - indicator of i-attribute belonging to j-subset.

If the purpose of the calculations is to establish the maturity of a certain type of business processes of a trade enterprise (business processes of the main activity, auxiliary, management, development) recognizing belonging of the actual characteristics of business processes by attributes to "unacceptable", "very poor", "poor", "not bad", "good", "very good" subsets, and level of the indicator is given in the table (Table 1).

Table 1

The result of recognizing the belonging of the actual characteristics of business process by attributes to "unacceptable", "very poor", "poor", "not bad", "good", "very good" subsets

\begin{tabular}{|c|l|c|c|c|c|c|c|c|c|}
\hline \multirow{2}{*}{ Type } & Attribute & Symbols & $\begin{array}{c}\text { Indicator } \\
\text { of } \\
\text { importance }\end{array}$ & $\begin{array}{c}\text { unacce } \\
\text { ptable, } \\
\mathrm{j}=1\end{array}$ & $\begin{array}{c}\text { very } \\
\text { poor, } \\
\mathrm{j}=2\end{array}$ & $\begin{array}{c}\text { poor, } \\
\mathrm{j}=3\end{array}$ & $\begin{array}{c}\text { not } \\
\text { bad, } \\
\mathrm{j}=4\end{array}$ & $\begin{array}{c}\text { good, } \\
\mathrm{j}=5\end{array}$ & $\begin{array}{c}\text { very } \\
\text { good, } \\
\mathrm{j}=6\end{array}$ \\
\hline \multirow{2}{*}{$\begin{array}{l}\text { Business } \\
\text { process }\end{array}$} & $\begin{array}{l}\text { Completeness } \\
\text { of business } \\
\text { process }\end{array}$ & Pm & $r_{p}$ & $\varphi_{p .1}$ & $\varphi_{p .2}$ & $\varphi_{p .3}$ & $\varphi_{p .4}$ & $\varphi_{p .5}$ & $\varphi_{p .6}$ \\
\cline { 2 - 12 } & $\begin{array}{l}\text { State of business } \\
\text { process taking } \\
\text { into account } \\
\text { the interests } \\
\text { of stakeholders }\end{array}$ & Gm & $r_{g}$ & $\varphi_{p .1}$ & $\varphi_{p .2}$ & $\varphi_{p .3}$ & $\varphi_{p .4}$ & $\varphi_{p .5}$ & $\varphi_{p .6}$ \\
\hline
\end{tabular}

\section{Source: Compiled by the author}

If the purpose of the calculations is to establish the maturity of process management and on this basis assess the level of economic security for the trade enterprise, recognizing the belonging of actual characteristics of business processes by attributes to "unacceptable", "very poor", "poor", "not bad", "good", "very good" subsets, level of the indicator is given in the table (Table 2).

\footnotetext{
${ }^{1}$ Недосекин, А. О. (2003). Методологические основы моделирования финансовой деятельности с использованием нечетко-множественных описаний: диссертация на соискание ученой степени доктора экономических наук. Санкт-Петербург: Санкт-Петербургский государственный университет экономики и финансов (ФИНЭК), 280. <http://www.mirkin.ru/_docs/doctor005.pdf> (2020, July, 10).
} 
The result of recognizing the belonging of the actual characteristics of business process by attributes to "unacceptable", "very poor", "poor", "not bad", "good", "very good" subsets

\begin{tabular}{|l|c|c|c|c|c|c|c|c|}
\hline \multirow{2}{*}{ Type } & \multirow{2}{*}{ Attribute } & \multirow{2}{*}{$\begin{array}{c}\text { Indicator of } \\
\text { importance }\end{array}$} & $\begin{array}{c}\text { unaccepta } \\
\text { ble, } \\
\mathrm{j}=1\end{array}$ & $\begin{array}{c}\text { very } \\
\text { poor, } \\
\mathrm{j}=2\end{array}$ & $\begin{array}{c}\text { poor, } \\
\mathrm{j}=3\end{array}$ & $\begin{array}{c}\text { not bad, } \\
\mathrm{j}=4\end{array}$ & $\begin{array}{c}\text { good, } \\
\mathrm{j}=5\end{array}$ & $\begin{array}{c}\text { very } \\
\text { good, } \\
\mathrm{j}=6\end{array}$ \\
\hline \multirow{2}{*}{$\begin{array}{l}\text { Business processes } \\
\text { of the main activity }\end{array}$} & $\mathrm{P}_{\mathrm{b}}$ & $r_{p b}$ & $\varphi_{p b .1}$ & $\varphi_{p b .2}$ & $\varphi_{p b .3}$ & $\varphi_{p b .4}$ & $\varphi_{p b .5}$ & $\varphi_{p b .6}$ \\
\cline { 5 - 10 } & $\mathrm{G}_{\mathrm{b}}$ & $r_{g b}$ & $\varphi_{g b .1}$ & $\varphi_{g b .2}$ & $\varphi_{g b .3}$ & $\varphi_{g b .4}$ & $\varphi_{g b .5}$ & $\varphi_{g b .6}$ \\
\hline \multirow{2}{*}{$\begin{array}{l}\text { Auxiliary business } \\
\text { processes }\end{array}$} & $\mathrm{P}_{\mathrm{h}}$ & $r_{p h}$ & $\varphi_{p h .1}$ & $\varphi_{p h .2}$ & $\varphi_{p h .3}$ & $\varphi_{p h .4}$ & $\varphi_{p h .5}$ & $\varphi_{p h .6}$ \\
\cline { 2 - 10 } & $\mathrm{G}_{\mathrm{h}}$ & $r_{g h}$ & $\varphi_{g h .1}$ & $\varphi_{g h .2}$ & $\varphi_{g h .3}$ & $\varphi_{g h .4}$ & $\varphi_{g h .5}$ & $\varphi_{g h .6}$ \\
\hline \multirow{2}{*}{$\begin{array}{l}\text { Management } \\
\text { business processes }\end{array}$} & $\mathrm{P}_{\mathrm{c}}$ & $r_{p c}$ & $\varphi_{p c .1}$ & $\varphi_{p c .2}$ & $\varphi_{p c .3}$ & $\varphi_{p c .4}$ & $\varphi_{p c .5}$ & $\varphi_{p c .6}$ \\
\cline { 2 - 10 } & $\mathrm{G}_{\mathrm{c}}$ & $r_{g c}$ & $\varphi_{g c .1}$ & $\varphi_{g c .2}$ & $\varphi_{g c .3}$ & $\varphi_{g c .4}$ & $\varphi_{g c .5}$ & $\varphi_{g c .6}$ \\
\hline \multirow{2}{*}{$\begin{array}{l}\text { Development } \\
\text { business processes }\end{array}$} & $\mathrm{P}_{\mathrm{d}}$ & $r_{p d}$ & $\varphi_{p d .1}$ & $\varphi_{p d .2}$ & $\varphi_{p d .3}$ & $\varphi_{p d .4}$ & $\varphi_{p d .5}$ & $\varphi_{p d .6}$ \\
\cline { 4 - 10 } & $\mathrm{G}_{\mathrm{d}}$ & $r_{g d}$ & $\varphi_{g d .1}$ & $\varphi_{g d .2}$ & $\varphi_{g d .3}$ & $\varphi_{g d .4}$ & $\varphi_{g d .5}$ & $\varphi_{g d .6}$ \\
\hline $\begin{array}{l}\text { Level of prosperity of } \\
\text { m-business process }\end{array}$ & & & 0.0 & 0.1 & 0.3 & 0.5 & 0.7 & 0.9 \\
\hline
\end{tabular}

\section{Source: Compiled by the author}

Based on the results of the calculation of the $\mathrm{Q}$ indicator, to identify the maturity of process management and the level of economic security at the enterprise (Table 3).

Conditions for identifying the level of economic security of a trade enterprise

\begin{tabular}{|l|l|}
\hline \multicolumn{1}{|c|}{ Q Values } & \multicolumn{1}{c|}{ Subset Name } \\
\hline 0.0 & $Q 1-$ the $0^{\text {th }}$ level (highest level of danger) \\
\hline$[0.0 \ldots 0.2]$ & $Q 2-$ the $1^{\text {st }}$ level (initial - low level of security) \\
\hline$[0.21 \ldots 0.40]$ & $Q 3-$ the $2^{\text {nd }}$ level (standard - minimum required security level); \\
\hline$[0.41 \ldots 0.60]$ & $Q 4-$ the $3^{\text {rd }}$ level (rational and formalized - sufficient level of security); \\
\hline$[0.61 \ldots 0.80]$ & $Q 5-$ the $4^{\text {th }}$ level (controlled and managed - high level of security); \\
\hline$[0.81 \ldots 1.0]$ & $\begin{array}{l}Q 6-\text { the } 5^{\text {th }} \text { level (ultimate with constant development }- \text { the highest (absolute) level } \\
\text { of security). }\end{array}$ \\
\hline
\end{tabular}

Source: Compiled by the author

To make a conclusion about the level of economic security of a trade enterprise.

Below are the results of practical evaluation of the developed scientific and methodological approach using the data of the trade enterprises, which are the largest enterprises in Ukraine according to the publications ${ }^{1}$. General information on enterprises is provided in table 4.

\footnotetext{
${ }^{1}$ Vereecke, A., Vanderheyden, K., Baecke, Ph., Van Steendam, T. (2018). Mind the gap - Assessing maturity of demand planning, a cornerstone of S\&OP. International Journal of Operations \& Production Management, 38, 8, 1618-1639. DOI:10.1108/IJOPM-11-2016-0698.
} 
Table 4

Information broken down for trade enterprises

\begin{tabular}{|l|c|c|c|c|c|c|c|c|}
\hline \multirow{2}{*}{ Enterprise } & \multicolumn{2}{|c|}{2015} & \multicolumn{2}{c|}{2016} & \multicolumn{2}{c|}{2017} & \multicolumn{2}{c|}{2018} \\
\cline { 2 - 9 } & $\begin{array}{l}\text { earnings, } \\
\text { bn UAH }\end{array}$ & $\begin{array}{l}\text { financials, } \\
\text { mm UAH }\end{array}$ & $\begin{array}{c}\text { earnings, } \\
\text { bn UAH }\end{array}$ & $\begin{array}{c}\text { financials, } \\
\text { mm UAH }\end{array}$ & $\begin{array}{c}\text { earnings, } \\
\text { bn UAH }\end{array}$ & $\begin{array}{c}\text { financials, } \\
\text { mm UAH }\end{array}$ & $\begin{array}{c}\text { earnings, } \\
\text { bn UAH }\end{array}$ & $\begin{array}{c}\text { financials, } \\
\text { mm UAH }\end{array}$ \\
\hline ATB-market & 38.4 & 2362.2 & 48.4 & 1605.4 & 66.3 & 2.3 & 85.7 & 2.7 \\
\hline $\begin{array}{l}\text { Silpo Food, } \\
\text { LLC }\end{array}$ & 35.0 & -1405.9 & 37.7 & -383.6 & 44.0 & -297.0 & 57.0 & 103.0 \\
\hline $\begin{array}{l}\text { Epicentr-K, } \\
\text { LLC }\end{array}$ & 22.7 & 1809.7 & 28.2 & 2434.1 & 33.7 & 2.8 & 41.5 & 3025.0 \\
\hline $\begin{array}{l}\text { METRO } \\
\text { Cash \& } \\
\text { Carry }\end{array}$ & 10.2 & -1969.1 & 11.8 & -671.3 & 14.5 & -1363.0 & 17.4 & 467.0 \\
$\begin{array}{l}\text { Ukraine, } \\
\text { LLC }\end{array}$ & 8.9 & -195.6 & 9.7 & 203.0 & 11.3 & 264.0 & 15.5 & -771.0 \\
\hline $\begin{array}{l}\text { Auchan } \\
\text { Ukraine } \\
\text { hypermarket } \\
\text { LLC }\end{array}$ & 6.7 & 64.9 & 7.6 & 78.8 & 9.4 & 84.0 & 12.2 & 84.0 \\
\hline $\begin{array}{l}\text { SAV- } \\
\text { Distribution, } \\
\text { LLC }\end{array}$ & 4.8 & 11.6 & 5.2 & 54.9 & 5.9 & 52.0 & 6.9 & 57.0 \\
\hline $\begin{array}{l}\text { Tavriia } \\
\text { Plius, PE }\end{array}$ & 4.3 & -379.2 & 5.6 & -98.8 & 7.3 & 59.0 & 9.1 & 290.0 \\
\hline $\begin{array}{l}\text { Novus } \\
\text { Ukraine, } \\
\text { LLC }\end{array}$ & 3.9 & 167.0 & 4.8 & 211.3 & 6.6 & 243.0 & 10.1 & 344.0 \\
\hline Rush, LLC & 19.5 & 6.7 & 65.9 & 7.8 & 68.0 & 9.7 & 54.0 \\
\hline Diesa, LLC & 6.1 & & & & & & \\
\hline
\end{tabular}

Source: authoring, sources used ${ }^{l}$.

The results of assessing the maturity of business processes and the conclusion on the level of their economic security are specified in table 5 .

Based on the results of calculations for the most of the trade enterprises under study, 3 and 4 levels of maturity of business processes have been found, which makes it possible to conclude about a sufficient level of their economic security. At the same time, Auchan Ukraine Hypermarket, LLC, and METRO Cash \& Carry Ukraine have higher values of maturity ratios both in general by business processes and by their types. For instance, if the average value of the maturity ratio for all business processes through the selection of the enterprises under study is set at 0.55 , then for these enterprises it is 0.63 and 0.80 respectively. The same situation is observed in terms of types of business processes.

\footnotetext{
${ }^{1}$ БизнесЦензор (2016). 200 найбільших компаній Украӥни 2015 року <https://biz.censor.net.ua/resonance/3011931/200_nayiblshih_kompanyi_ukrani_2015_roku>(2020, July, 10); БизнесЦензор (2017). 200 найбільиих компаній Украӥни 2016 року. <https://biz.censor.net.ua/resonance/3033764/200_nayiblshih_kompanyi_ukrani_2016_roku> (2020, July, 10); БизнесЦензор (2018). 200 найбільших компаній Украӥни 2017 року. <https://biz.censor.net.ua/resonance/3084420/200_nayiblshih_kompanyi_ukrani_2017_roku> (2020, July, 10); БизнесЦензор (2019). 200 найбільших компаній Украӥни 2018 року. <https://biz.censor.net.ua/resonance/3147570/200_nayiblshih_kompanyi_ukrani_2018_roku>(2020, July, 10).
} 
告

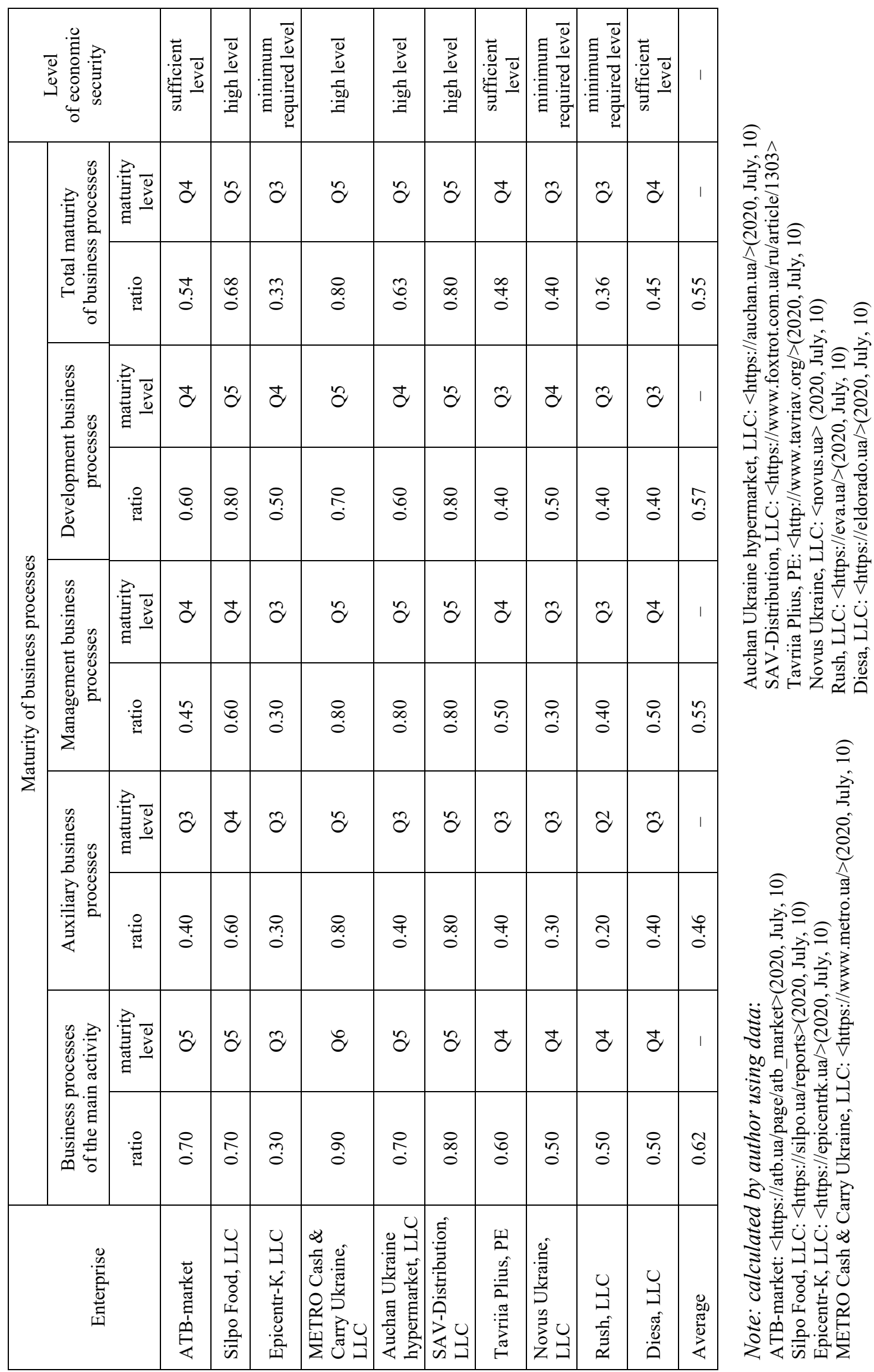


Against the background of the ratios, corresponding to 3... 4 level of maturity, Auchan Ukraine Hypermarket, LLC and METRO Cash \& Carry Ukraine have much higher maturity of business processes, namely 0.70 and 0.90 against 0.62 for the main business processes; 0.80 against 0.55 for management processes, and 0.60 and 0.70 against 0.57 for development processes. Higher values of maturity ratios for these trade enterprises are explained by their inclusion in the global trade networks (Auchan Holding, Metro AG) with a high level of standards of activity and processes.

Conclusions. The results of the conducted research substantiate the scientific and methodical approach for assessing economic security of the trade enterprise on the basis of maturity of its business processes. The developed approach is based on the method of fuzzy logic, which makes it possible to establish the level of economic security of the trade enterprise on the basis of the maturity of its business processes with incomplete data available. The developed approach contains two types of maturity assessment - individual business processes and process management at the enterprise as a whole - and provides for step-by-step calculations for assessing the state of business processes of a trade enterprise, taking into account the interests of stakeholders, identifying the completeness of business process, assessing the business processes maturity, and establishing the type of economic security at the enterprise. To implement the developed scientific and methodological approach, a system of indicators is substantiated which is formed taking into account the criteria of performance, efficiency, and satisfaction of consumers with the results of the business process.

Practical evaluation of the developed scientific and methodical approach according to the selection of trade networks has proved its efficiency and the possibility of implementation in the operation of trade enterprises. The results of the calculations have made it possible to come to a conclusion about the balanced state of process management at the enterprises under study, which is confirmed by the maturity ratios, the values of which correspond to $3 \ldots 4$ levels of process maturity. At the same time, as a result of a comparative analysis of trade enterprises that belong to international trade networks, higher values of business process ratios have been established compared to other enterprises and the selection as a whole.

\section{References:}

1. Tarhan, A., Turetken, O., Reijers, A.H. (2016). Business process maturity models: A systematic literature review. Information and Software Technology, 75, 122-134. DOI:10.1016/j.infsof.2016.01.010. [in English].

2. Roeglinger, M., Poeppelbuss, J., Becker, J. (2012). Maturity Models in Business Process Management. Business Process Management Journal, 18(2), 328-346. DOI: 10.1108/14637151211225225. [in English].

3. Bruin, T., Kulkarni, U., Rosemann. M., Freeze, D.R. (2005). Understanding the Main Phases of Developing a Maturity Assessment Model. 16th Australasian Conference on Information Systems. Sydney. $<$ https://pdfs.semanticscholar.org/c00f/91faf37a75823a5baca7415a5123ac4010f8.pdf>(2020, July, 10). [in English].

4. Rohloff, M. (2011). Advances in business process management implementation based on a maturity assessment and best practice exchange. Information Systems and e-Business Management, 9, 383-403. DOI:10.1007/s10257010-0137-1. [in English].

5. Sliż, P. (2018). Concept of the Organization Process Maturity Assessment. Journal of Economics and Management, 33(3), 80-95. DOI: 10.22367/jem.2018.33.05 [in English].

6. Paulk, M. C., Chrissis, M. B., Weber, C. (1993). Capability Maturity Model for Software (Version 1.1). Technical report. 〈https://resources.sei.cmu.edu/library/asset-view.cfm?assetid=11955>>(2020, July, 10). [in English].

7. Carolis, A.De, Macchi, M., Negri, E., Terzi, S.A. (2017). Maturity Model for Assessing the Digital Readiness of Manufacturing Companies. IFIP WG 5.7. International Conference, APMS, Hamburg, Germany, Proceedings, 1 , 13-20. <https://link.springer.com/chapter/10.1007/978-3-319-66923-6_2>(2020, July, 10) [in English].

8. Garousi, V., Felderer, M., Hacaloglu, T. (2017). Software test maturity assessment and test process improvement: A multivocal literature review. Information and Software Technology. DOI:10.1016/. [in English].

9. Vivares, A. J., Sarache, W., Hurtado, J. (2018). A maturity assessment model for manufacturing systems. Journal of Manufacturing Technology Management, 29, 5, 746-767. DOI:10.1108/JMTM-07-2017-0142. [in English].

10. Zare, S. M., Tahmasebi, R., Yazdani, H. (2018). Maturity assessment of HRM processes based on HR process survey tool: a case study. Business Process Management Journal, 24, 3, 610-634. DOI:10.1108/BPMJ-01-2017-0008. [in English].

11. Vereecke, A., Vanderheyden, K., Baecke, Ph., Van Steendam, T. (2018). Mind the gap - Assessing maturity of demand planning, a cornerstone of S\&OP. International Journal of Operations \& Production Management, 38, 8, 1618-1639. DOI:10.1108/IJOPM-11-2016-0698. [in English].

12. Vasyltsiv, T. H., Voloshyn, V. I., Boikevych, O. R., Karkavchuk, V. V. (2012). Finansovo-ekonomichna bezpeka pidpryiemstv Ukrainy: stratehiia ta mekhanizmy zabezpechennia [Financial and economic security of Ukrainian enterprises: strategy and enforcement mechanisms]. Lviv: Liha-Pres. 〈http://ird.gov.ua/irdp/p20120802.pdf> (2020, July, 10). [in Ukrainian]. 
13. Pylypenko, A. A., Pylypenko, S. M. (2019). Otsiniuvannia zrilosti lohistychnoi diialnosti v upravlinni ekonomichnoiu bezpekoiu rozvytku obiednan torhovelnykh pidpryiemstv [Assessment of the maturity of logistics activities in the management of economic security of the development of associations of commercial enterprises]. Biznes-navihator [Business Navigator], 6.1-1(56), 219-222. [in Ukrainian].

14. ISO 9000:2015 (2015). Quality management systems - Fundamentals and vocabulary <https://www.iso.org/ru/standard/45481.html>(2020, July, 10). [in English].

15. Korol, S. Ya. (2016). Sotsialna vidpovidalnist biznesu: teoriia ta metodolohiia obliku [Business social responsibility: accounting theory and methodology]. Kyiv: KNTEU. [in Ukrainian].

16. Klebanova, T. S. Chahovets, L. O., Panasenko, O. V. (2011). Nechitka lohika ta neironni merezhi v upravlinni pidpryiemstvom [Fuzzy logic and neural networks in enterprise management]. Kharkiv: INZhEK. [in Ukrainian].

17. Nedosekin, A. O. (2003). Metodologicheskie osnovy modelirovaniya finansovoj deyatelnosti s ispolzovaniem nechetko-mnozhestvennyh opisanij [Methodological basis of modeling of financial activity with use of is indistinctplural descriptions]: dissertatsiya na soiskaniye uchenoy stepeni doktora ekonomicheskikh nauk [dissertation for the degree of Doctor of Economics]. Saint Petersburg: Saint Petersburg State University of Economics and Finance (FINEC) <http://www.mirkin.ru/_docs/doctor005.pdf> (2020, July, 10). [in Russian].

18. ByznesTsenzor (2016) [BusinessCensor (2016)]. 200 naybilshykh kompaniy Ukrayiny 2015 roku [200 largest companies in Ukraine in 2015]. <https://biz.censor.net.ua/resonance/3011931/200_nayiblshih_kompanyi_ukrani_ 2015_roku>>(2020, July, 10) [in Ukrainian].

19. ByznesTsenzor (2017) [BusinessCensor (2017)]. 200 naybilshykh kompaniy Ukrayiny 2016 roku [200 largest companies in Ukraine in 2016]. <https://biz.censor.net.ua/resonance/3033764/200_nayiblshih_kompanyi_ukrani_ 2016_roku>>(2020, July, 10) [in Ukrainian].

20. ByznesTsenzor (2018) [BusinessCensor (2018)]. 200 naybilshykh kompaniy Ukrayiny 2017 roku [200 largest companies in Ukraine in 2017]. <https://biz.censor.net.ua/resonance/3084420/200_nayiblshih_kompanyi_ukrani_ 2017_roku>>(2020, July, 10) [in Ukrainian].

21. ByznesTsenzor (2019) [BusinessCensor (2019)]. 200 naybilshykh kompaniy Ukrayiny 2018 roku [200 largest companies in Ukraine in 2018]. <https://biz.censor.net.ua/resonance/3147570/200_nayiblshih_kompanyi_ukrani_ 2018_roku>>(2020, July, 10) [in Ukrainian]. 